\title{
Ruminal escape and intestinal digestibility of ruminally protected lysine supplements differing in oleic acid and lysine concentrations
}

\author{
Z. Wu, ${ }^{*}$ J. K. Bernard, ${ }^{\star 1}{ }^{1}$ R. B. Eggleston, $†$ and T. C. Jenkinsł \\ *Department of Animal and Dairy Science, University of Georgia, Tifton 31793-5766 \\ †Department of Large Animal Medicine, University of Georgia, Athens 30602-7385 \\ ¥Department of Animal and Veterinary Sciences, Clemson University, Clemson, SC 29634-0001
}

\section{ABSTRACT}

This trial was conducted to determine the effect of the addition of 2 or $4 \%$ oleic acid to an hydrogenated fat coating applied to an experimental supplement with 55 or $58 \%$ lysine sulfate on ruminal escape and intestinal absorption of Lys. Two lactating Holstein cows (103 d in milk and $45.1 \mathrm{~kg} / \mathrm{d}$ of milk) previously fitted with ruminal and duodenal cannulas were individually housed and fed a corn silage-based ration. In situ and mobile bag techniques were utilized to evaluate the 4 test products. Twenty bags of each product were incubated for $16 \mathrm{~h}$ in each cow to determine ruminal escape. After ruminal incubation, products were repackaged, soaked in pepsin $/ \mathrm{HCl}$ solution for $2 \mathrm{~h}$, inserted into the duodenum, and subsequently collected in the feces. The percentage of dry matter and fat escaping the rumen decreased as oleic acid increased from 2 to $4 \%$ or as the proportion of supplemental Lys increased. An interaction was observed because of a greater reduction of $\mathrm{N}$ and Lys escaping ruminal fermentation and flowing to the small intestine for the product with $58 \%$ supplemental Lys and $4 \%$ oleic acid compared with the other products. No differences were observed in intestinal digestibility of dry matter, N, Lys, or fat or in the amount of Lys digested in the small intestine. Increasing the proportion of oleic acid in the coating applied to supplemental Lys increased ruminal degradation. The extent of the degradation increased as the proportion of Lys in the product increased.

Key words: rumen-protected lysine, ruminal escape, intestinal digestibility

\section{INTRODUCTION}

Protein is important for optimizing milk yield and minimizing $\mathrm{N}$ release into the environment (Dinn et al., 1998). In ruminants, the microorganisms in the reticu-

Received November 28, 2011.

Accepted January 8, 2012.

${ }^{1}$ Corresponding author: jbernard@uga.edu lorumen degrade much of the protein consumed to ammonia and peptides, which are then used to synthesize microbial protein, but excess ammonia is absorbed into the bloodstream where it can be recycled or excreted as urea in the urine (Satter and Roffler, 1975). Microbial protein passes out of the rumen into the small intestine where it is digested and the AA absorbed. Microbial protein is very high quality because of the high proportion of essential AA and balance relative to muscle and milk protein composition (NRC, 2001). The proportion of dietary protein that is not degraded enters the small intestine, where it is digested and provides additional AA that could be used to meet the $\mathrm{N}$ requirements of the animal (NRC, 2001). The quality of the dietary protein escaping ruminal degradation is important for supplying additional essential AA to meet overall requirements.

Lysine and Met have been reported to be co-limiting AA for growth and milk synthesis in dairy cattle (Clark, 1975; Schwab et al., 1976; Nichols et al., 1998; Socha et al., 2005). Because most sources of supplemental individual AA are rapidly degraded by ruminal microorganisms before absorption, it has not been practical to supplement diets with individual AA until recently. Considerable research has been conducted over the past 3 decades to develop technologies to protect AA. Ruminal-protected Met has been available for feeding ruminants for several years (Papas et al., 1984; Overton et al., 1998; Patton, 2010), which allows more precise formulation, but technology for producing ruminally protected Lys and other AA has not been as successful.

In recent years, various groups have developed technologies in which lipid coatings have been applied to supplemental Lys to protect it from degradation in the rumen (Ardaillon et al., 1989; Ardaillon and Franzoni, 1992; Rappoport, 1999). These coatings appear to provide protection from degradation by the ruminal microorganisms (Smith and Boling, 1984; Papas and Wu, 1997), but data are lacking on the digestibility of these products in the small intestine. Hydrogenated fatty acids have been used as a coating to protect various compounds, but hydrogenated fatty acids are poorly 
digested in the small intestine compared with unsaturated fatty acids (Pantoja et al., 1996; Harvatine and Allen, 2006). Previous research has shown that inclusion of PUFA, such as oleic acid, along with a primarily saturated fatty acid may improve overall FA digestibility in the small intestine (Drackley et al., 2007).

The objective of this study was to determine the effect of adding 2 or $4 \%$ oleic acid to a hydrogenated fat coating applied to an experimental supplement containing 55 or $58 \%$ supplemental lysine sulfate on ruminal escape and intestinal digestibility of an experimental protected Lys supplement using the mobile bag technique.

\section{MATERIALS AND METHODS}

Four experimental products were produced for the trial with a $2 \times 2$ factorial arrangement of treatments to provide 55 (L55) or $58 \%$ (L58) lysine sulfate and $2($ O2) or $4 \%$ (O4) concentrations of oleic acid $(78 \%$ purity) in the final product. Lysine sulfate was coated with a blend of hydrogenated rapeseed oil plus oleic acid at the IPC Process Center GmbH \& Co. KG (Dresden, Germany) using a proprietary process. The product was shipped to the University of Georgia Tifton campus for the trial.

All protocols were approved by the University of Georgia Institute for Animal Care and Use before the trial. Two lactating multiparous Holstein cows (103 DIM and $45.1 \mathrm{~kg} / \mathrm{d}$ of milk) previously fitted with flexible ruminal and duodenal cannulas were used for the mobile bag trial (NRC, 2001). Cows were housed in individual pens and fed a corn silage-based ration once daily at $0700 \mathrm{~h}$. The diet was composed of (\% of DM): $33.11 \%$ corn silage, $9.35 \%$ ryegrass silage, $4.68 \%$ alfalfa hay, $6.75 \%$ whole cottonseed, $12.63 \%$ wet brewers grains, $17.77 \%$ ground corn, and $15.71 \%$ concentration containing supplemental protein, minerals, and vitamins. Cows had free access to water throughout the trial. To determine ruminal degradability, approximately $5 \mathrm{~g}$ of each product or soybean meal was weighed into $10-x$ 20-cm nitrogen-free nylon bags with a pore size of $50 \pm$ $15 \mu \mathrm{m}$ (Ankom Technology, Macedon, NY). The top of each bag was heat-sealed 3 times to prevent any sample from escaping. At 1600 h, 1 mesh bag with 20 bags of each product plus 2 blank bags per cow was inserted through the ruminal cannula into the ventral sac of the rumen and incubated for $16 \mathrm{~h}$ (Kononoff et al., 2007). After rumen incubation, all bags were removed and immediately hand rinsed in cold water to stop microbial activity and then machine washed with cold water to remove any microbial or feed contamination. Following washing, all bags were dried in a forced-air oven and weighed. After weighing, samples were composited by treatment within cow and a subsample collected for chemical analysis.

Intestinal digestibility was determined by weighing approximately $0.8 \mathrm{~g}$ of the composited residue remaining after ruminal incubation into $5-\times 10$-cm nitrogenfree nylon bags with a pore size of $50 \pm 15 \mu \mathrm{m}$ (Ankom Technology) and sealing as described above. The bags were incubated in a pepsin- $\mathrm{HCl}$ solution $(100 \mathrm{mg}$ of pepsin/L of $0.01 \mathrm{~N} \mathrm{HCl}$ ) for $2 \mathrm{~h}$ at $39^{\circ} \mathrm{C}$ in a shaking water bath to simulate abomasal digestion. Pepsin- $\mathrm{HCl}$ was added in amounts required to decrease the $\mathrm{pH}$ to 2.4. After incubation, bags were rinsed with distilled water and stored at $-18^{\circ} \mathrm{C}$ until introduction into the duodenum. Bags were inserted into the duodenum through the duodenal fistula beginning at $0900 \mathrm{~h}$. One bag was inserted every 15 min to permit movement of previous bags through the intestine to avoid compaction. Each session lasted $4 \mathrm{~h}$ and was followed by a minimum of $8 \mathrm{~h}$ of rest before the next session. This process was repeated until all bags had been inserted into the duodenum. Bags were recovered from the feces approximately 8 to $16 \mathrm{~h}$ after initial insertion. Collected bags were immediately hand rinsed in cold water to remove any fecal material and dried in a forced-air oven. After drying, bags were weighed to determine residue weight. Samples were composited by treatment within cow and subsampled for chemical analysis.

Samples of raw material and rumen and fecal composites were analyzed for concentrations of DM, N, Lys, and acid hydrolysis fat (AOAC, 2006). Ruminal escape and intestinal digestibility of DM, N, Lys, and fat were calculated. Rumen escape percentage was calculated as the residue remaining after $16 \mathrm{~h}$ of incubation divided by the amount of raw material weighed into the bag. Intestinal digestibility percentage was calculated as 1 minus the residue remaining in the bag divided by the amount of ruminal residue weighed into the bag.

Data were subjected to ANOVA using PROC GLM (SAS Institute Inc., Cary, NC). The model included cow, main effects of Lys and oleic acid and their interaction, and error. When an interaction was detected $(P<$ $0.05)$, the PDIFF option was used for mean separation.

\section{RESULTS AND DISCUSSION}

The ingredient and chemical composition of the experimental ruminally protected Lys supplements are presented in Table 1. The composition of the experimental products was in agreement with formulations. The calculated concentration of oleic acid (C18:1) increased from 1.56 to $3.12 \%$ of DM as the proportion in the mix increased. 
WU ET AL.

Table 1. Ingredient and chemical composition of experimental protected Lys supplements

\begin{tabular}{|c|c|c|c|c|}
\hline \multirow[b]{2}{*}{ Item } & \multicolumn{4}{|c|}{ Lys supplement $^{1}$} \\
\hline & $\mathrm{L} 55 \mathrm{O} 2$ & $\mathrm{~L} 55 \mathrm{O} 4$ & $\mathrm{~L} 58 \mathrm{O} 2$ & L5804 \\
\hline \multicolumn{5}{|c|}{ Ingredient composition, $\%$} \\
\hline Lysine sulfate & 55 & 55 & 58 & 58 \\
\hline Hydrogenated fat ${ }^{2}$ & 43 & 41 & 40 & 38 \\
\hline Oleic acid & 2 & 4 & 2 & 4 \\
\hline \multicolumn{5}{|c|}{ Chemical composition, \% of DM } \\
\hline $\mathrm{N}$ & 6.85 & 6.86 & 7.24 & 7.17 \\
\hline Lys & 29.09 & 29.41 & 29.65 & 30.08 \\
\hline $\mathrm{Fat}^{3}$ & 43.99 & 43.70 & 41.57 & 41.67 \\
\hline $\mathrm{C} 16: 0^{4}$ & 2.71 & 2.58 & 2.52 & 2.39 \\
\hline $\mathrm{C} 18: 0^{4}$ & 38.96 & 37.19 & 36.24 & 34.47 \\
\hline $\mathrm{C} 18: 1^{4}$ & 1.56 & 3.12 & 1.56 & 3.12 \\
\hline $\mathrm{C} 22: 0^{4}$ & 0.22 & 0.21 & 0.20 & 0.19 \\
\hline \multicolumn{5}{|c|}{$\begin{array}{l}{ }^{1} \mathrm{~L} 55 \mathrm{O} 2=55 \% \text { lysine sulfate and } 2 \% \text { oleic acid; L55O } 4=55 \% \text { lysine sulfate and } 4 \% \text { oleic acid; L58O2 }=58 \\
\text { lysine sulfate and } 2 \% \text { oleic acid; and L58O } 4=58 \% \text { lysine sulfate and } 4 \% \text { oleic acid. }\end{array}$} \\
\hline
\end{tabular}

Ruminal escape and intestinal digestibility of experimental Lys supplements are presented in Table 2. The proportions of DM and fat escaping the rumen decreased as both the proportion of supplemental Lys in the product increased $(P=0.001)$ from 55 to $58 \%$ and as the percentage of oleic acid composition increased $(P=0.005)$ from 2 to $4 \%$. An interaction was observed between the proportion of supplemental Lys and oleic acid for ruminal escape of $\mathrm{N}(P=0.05)$ and Lys $(P=$ 0.01 ) because the proportion escaping the rumen was higher for $\mathrm{L} 55 \mathrm{O} 2$ and $\mathrm{L} 55 \mathrm{O} 4$ than for $\mathrm{L} 58 \mathrm{O} 4$.

No differences were observed in the intestinal digestibility of DM, N, Lys, or fat among treatments (Table
2). However, the proportion of Lys flowing to the small intestine was lower for L58O4 compared with the other treatments, resulting in an interaction between the proportion of Lys and oleic acid in the proportion of Lys flowing to small intestine $(P=0.01)$. Total grams of Lys digested in the small intestine did not differ among treatments. The calculated proportion of Lys that escaped ruminal degradation and was digested was 38.4, 41.2, 39.0, and 39.5\% for L55O2, L55O4, L58O2, and $\mathrm{L} 58 \mathrm{O} 4$, respectively.

Limited data are available on the characteristics of ruminally protected Lys supplements. Watanabe et al. (2003) evaluated the ruminal and intestinal digestibil-

Table 2. Ruminal escape ${ }^{1}$ and intestinal digestibility of experimental protected Lys supplements containing 55 or $58 \%$ lysine sulfate with 2 or $4 \%$ oleic acid in the coating

\begin{tabular}{|c|c|c|c|c|c|c|c|c|}
\hline \multirow[b]{2}{*}{ Item } & \multicolumn{4}{|c|}{ Treatment $^{2}$} & \multirow[b]{2}{*}{$\mathrm{SE}$} & \multicolumn{3}{|c|}{$P$-value } \\
\hline & L55O2 & L5504 & L58O2 & L58O4 & & Oleic $(\mathrm{O})$ & Lysine (L) & $\mathrm{O} \times \mathrm{L}$ \\
\hline $\mathrm{N}$ & $89.9^{\mathrm{a}}$ & $89.3^{\mathrm{a}}$ & $85.0^{\mathrm{ab}}$ & $75.6^{\mathrm{c}}$ & 1.4 & 0.04 & 0.007 & 0.05 \\
\hline Lys & $86.2^{\mathrm{a}}$ & $86.2^{\mathrm{a}}$ & $89.2^{\mathrm{a}}$ & $74.2^{\mathrm{b}}$ & 1.3 & 0.01 & 0.04 & 0.01 \\
\hline Fat & 94.9 & 92.6 & 84.3 & 77.8 & 1.9 & 0.10 & 0.006 & 0.34 \\
\hline $\mathrm{N}$ & 38.3 & 38.7 & 41.2 & 47.9 & 3.3 & 0.36 & 0.17 & 0.42 \\
\hline Lys & 44.5 & 47.8 & 43.7 & 53.3 & 5.9 & 0.46 & 0.56 & 0.48 \\
\hline Fat & 28.1 & 29.2 & 27.0 & 24.3 & 4.2 & 0.86 & 0.52 & 0.68 \\
\hline \multicolumn{9}{|l|}{ Lys } \\
\hline Flow to small intestine, $\%$ & $25.1^{\mathrm{a}}$ & $25.3^{\mathrm{a}}$ & $26.4^{\mathrm{a}}$ & $22.3^{\mathrm{b}}$ & 0.4 & 0.02 & 0.13 & 0.01 \\
\hline Digested in small intestine, \% & 11.2 & 11.4 & 11.5 & 11.9 & 1.4 & 0.85 & 0.77 & 0.96 \\
\hline
\end{tabular}

${ }^{\mathrm{a}-\mathrm{c}}$ Means within a row with different superscripts differ $(P<0.05)$.

${ }^{1}$ Measured after 16 -h incubation in the rumen.

${ }^{2} \mathrm{~L} 55 \mathrm{O} 2=55 \%$ lysine sulfate and $2 \%$ oleic acid; L55O $4=55 \%$ lysine sulfate and $4 \%$ oleic acid; L58O2 = 58\% lysine sulfate and $2 \%$ oleic acid; and $\mathrm{L} 58 \mathrm{O} 4=58 \%$ lysine sulfate and $4 \%$ oleic acid. 
ity of a protected Lys that was coated with dehydrogenated tallow. When fed to steers, $58.3 \%$ of the Lys was recovered in the abomasal outflow during the 48-h sampling period, with peak recovery occurring between 12 and $16 \mathrm{~h}$ after administration. The passage rate of the steers used in this trial would be lower than that of a high-producing lactating cow, so the proportion of Lys flowing to the small intestine would be expected to be greater than reported in this study. Watanabe et al. (2003) reported that $49.5 \%$ flowing out of the abomasums disappeared in the small intestine.

Swanepoel (2009) evaluated a protected Lys product produced by forming a matrix of L-Lys-HCl and ruminally protected fatty acids with a $\mathrm{pH}$-sensitive intestinal release mechanism. Results of the in situ study indicated that $13 \%$ of the $\mathrm{N}$ in the product was soluble in the rumen, with 58,50 , and $39 \%$ of the $\mathrm{N}$ remaining after 24,36 , and $48 \mathrm{~h}$ of incubation, respectively. Assuming a rate of passage of $0.05 / \mathrm{h}$ for a high-producing cow, Swanepoel (2009) reported that $52.6 \%$ of the N would have escaped ruminal degradation. Robinson et al. (2010) reported intestinal availability ranging from 47 to $57 \%$ in a subsequent trial in which the product was fed to lactating cows.

Addition of $4 \%$ oleic acid increased ruminal degradability of $\mathrm{N}$ and Lys compared with products with $2 \%$ oleic acid, suggesting that the hydrogenated fat coating was more susceptible to ruminal degradation as the oleic acid content increased. This is consistent with observations of Harvatine and Allen (2006), who reported linear increases in intestinal fatty acid digestibility with increasing unsaturated fatty acid supplements. However, we did not observe any difference in intestinal digestibility of fat as the percentage of oleic acid increased. Intestinal digestibility of $\mathrm{N}$ and Lys were numerically highest for the product with $58 \%$ Lys and $4 \%$ oleic acid, suggesting that the higher oleic acid content could support improved digestibility. This is consistent with Drackley et al. (2007), who reported that total fatty acid digestibility increased linearly as infused oleic acid increased.

\section{CONCLUSIONS}

Increasing the proportion of oleic acid or the proportion of lysine sulfate lowered ruminal escape and, thus, increased ruminal degradation of Lys. Inclusion of oleic acid in the coating numerically improved intestinal digestibility, increasing potential metabolizable Lys concentrations. However, increasing the concentration of both Lys and oleic acid increased susceptibility to ruminal degradation and reduced the amount of Lys delivered to the small intestine. Data on the metabo- lizable Lys content of protected Lys supplements are important for formulating rations that can be fed to lactating dairy cows to improve $\mathrm{N}$ efficiency and production.

\section{ACKNOWLEDGMENTS}

The authors thank Natasha Mullis and Melissa Tawzer (both of Department of Animal and Dairy Science, University of Georgia, Tifton) for their assistance with animal care and sample preparation and processing.

\section{REFERENCES}

AOAC. 2006. Official Methods of Analysis. 18th ed. Association of Official Analytical Chemists, Arlington, VA.

Ardaillon, P., P. Antant, P. Bourrain, and A. Cartillier, inventors. 1989. Compositions for coating feedstuff additives thus coated. Rhone-Poulenc Santé, assignee. US Pat. No. 4,877,621.

Ardaillon, P., and C. Franzoni. 1992, inventors. Enzymatically degradable coating compositions for feed additives intended for ruminants. Rhone-Poulenc Santé, assignee. US Pat. No. 5,098,718.

Clark, J. H. 1975. Lactational responses of postruminal administration of proteins and amino acids. J. Dairy Sci. 58:1178-1197.

Dinn, N. E., J. A. Shelford, and L. J. Fisher. 1998. Use of the Cornell Net Carbohydrate and Protein System and rumen-protected lysine and methionine to reduce nitrogen excretion from lactating dairy cows. J. Dairy Sci. 81:229-237.

Drackley, J. K., T. R. Overton, G. Ortiz-Gonzalez, A. D. Beaulieu, D. M. Barbano, J. M. Lynch, and E. G. Perkins. 2007. Responses to increasing amounts of high-oleic sunflower fatty acids infused into the abomasum of lactating dairy cows. J. Dairy Sci. 90:51655175 .

Harvatine, K. J., and M. S. Allen. 2006. Effects of fatty acid supplements on ruminal and total tract nutrient digestion in lactating dairy cows. J. Dairy Sci. 89:1092-1103.

Kononoff, P. J., S. K. Ivan, and T. J. Klopfenstein. 2007. Estimation of the proportion of feed digested in the small intestine of cattle consuming wet corn gluten feed. J. Dairy Sci. 90:2377-2385.

NRC (National Research Council). 2001. Nutrient Requirements of Dairy Cattle. 7th rev. ed. Natl. Acad. Sci., Washington, DC.

Nichols, J. R., D. J. Schingoethe, H. A. Maiga, M. J. Brouk, and M. S. Piepenbrink. 1998. Evaluation of corn distillers grains and ruminally protected lysine and methionine for lactating dairy cows. J. Dairy Sci. 81:482-491.

Overton, T. R., L. S. Emmert, and J. H. Clark. 1998. Effects of source of carbohydrate and protein and rumen-protected methionine on performance of cows. J. Dairy Sci. 81:221-228.

Pantoja, J., J. L. Firkins, and M. L. Eastridge. 1996. Fatty acid digestibility and lactation performance by dairy cows fed fats varying in degree of saturation. J. Dairy Sci. 79:429-437.

Papas, A., and S. H. Wu. 1997. Rumen-stable delivery systems. Adv. Drug Deliv. Rev. 28:323-334.

Papas, A. M., C. J. Sniffen, and T. V. Muscato. 1984. Effectiveness of rumen-protected methionine for delivering methionine postruminally in dairy cows. J. Dairy Sci. 67:545-552.

Patton, R. A. 2010. Effect of rumen-protected methionine on feed intake, milk production, true milk protein concentration, and true milk protein yield, and the factors that influence these effects: A meta-analysis. J. Dairy Sci. 93:2105-2118.

Rappoport, L., inventor. 1999. Oleic acid as an additive for a protective coating. 3 L \& T Inc., assignee. US Pat. No. 5,997,953.

Robinson, P. H., S. Juchem, and I. Shinzato. 2010. Productivity of lactating dairy cows as impacted by feeding lysine in a ruminally protected form. J. Dairy Sci. 93(Suppl. 1):842. (Abstr.) 
Satter, L. D., and R. E. Roffler. 1975. Nitrogen requirements and utilization in dairy cattle. J. Dairy Sci. 58:1219-1237.

Schwab, C. G., L. D. Satter, and A. B. Clay. 1976. Response of lactating dairy cows to abomasal infusion of amino acids. J. Dairy Sci 59:1254-1270.

Smith, S. I., and J. A. Boling. 1984. Lipid coating as a mode of protecting free methionine from ruminal degradation. J. Anim. Sci. $58: 187-193$.

Socha, M. T., D. E. Putnam, B. D. Garthwaite, N. L. Whitehouse, N. A. Kierstead, C. G. Schwab, G. A. Ducharme, and J. C. Robert. 2005. Improving intestinal amino acid supply of pre- and postpar- tum dairy cows with rumen-protected methionine and lysine. J. Dairy Sci. 88:1113-1126.

Swanepoel, N. 2009. Estimating amino acid limitations in California dairy rations and the effect of feeding a ruminally protected lysine supplement on animal performance. MS Thesis. University of Pretoria, Pretoria, South Africa.

Watanabe, K., H. Sato, K. Katoh, and Y. Obara. 2003. Determination of intestinal disappearance of lysine and methionine derived from ruminally protected lysine and methionine in Holstein heifers. Asian-australas. J. Anim. Sci. 16:549-554. 